doi: $10.19090 / \mathrm{i} .2020 .31 .7-23$

UDC: $638.16: 255$

ISTRAŽIVANJA

JOURNAL OF HISTORICAL RESEARCHES

$31(2020)$
ORIGINAL SCIENTIFIC PAPER

Received: 7 May 2020

Accepted: 30 September 2020

\author{
ANGUS BOWIE \\ University of Oxford \\ The Queen's College \\ angus.bowie@queens.ox.ac.uk
}

\title{
THE RITUAL ROLE OF HONEY IN ANCIENT EGYPT, HATTI AND GREECE
}

\begin{abstract}
This is a comparison between the uses of honey in ritual contexts in the cultures of ancient Egypt, Hatti and Greece. Strong differences are illustrated. In Egypt, more particularly Lower Egypt, honey plays an important role in royal rituals linking the power, health and fertility of gods and pharaohs. By contrast among the Hittites honey, though involved in important rituals, especially those intended to 'sweeten' gods and make them appear amongst the gods or men, is only one ingredient among many. In Greece there appears to be a difference between Mycenaean times, when as far as the sparse evidence allows us to see honey was not restricted to particular types of god, and the Archaic and Classical periods, when it was very substantially confined to rites of an abnormal kind, rites evoking past ages and rites concerning the Underworld and the dead. The article ends with reflections on the limitations of such a comparison as this, and speculation on the reasons for the differences noted. Though the evidence must perforce be laid out very selectively, a range of original sources is quoted.
\end{abstract}

Keywords: Honey, ancient Egypt, Hittites, Crete, ancient Greece, kingly authority, chthonic ritual, evocatio of gods, curses, normal and abnormal ritual.

$\mathrm{T}$

This article is an attempt to compare the use of honey in the ritual activities of three cultures. I am not a specialist in all three cultures, and the topic is enormous, so no attempt has been made at comprehensiveness, and I have had to rely on secondary sources especially for Egypt. ${ }^{1}$ I have tried to deal with the major cases of the use of honey, setting out the main sources I have found. In the study of ancient cultures, there is the problem of whether words translated 'honey' actually refer to the substance created by bees or whether other kinds of sweetener are involved, ${ }^{2}$ but the three civilisations I discuss had been major bee-honey producers for many years. I have not included the Mesopotamian peoples, where honey had to be imported, because of the difficulty of knowing which sweet

\footnotetext{
For broad general treatments of honey in ancient times, see Chauvin 1968: 35-60; Crane 1975: 453-462.

On the history of Indo-European terms for honey and the problem of what exactly may be meant by the different terms see Le Sage 1975; on the question of other sweeteners, see also Kelhoffer 2005.
} 
substance is meant. ${ }^{3}$ The concentration on honey when it is used with other substances can be a little artificial. However, broad outlines of its use in these civilisations should appear.

\section{Egypt}

The earliest honey (bit) discovered in Egypt dates from the tomb of Tutankhamun (c. 1342-25), ${ }^{4}$ and artistic evidence for bee-keeping starts around 2400 on the temple of Newoserre Any near Abusir, though the practice went back long before that. Harvesting honey goes back at least to 6000 and Egypt, especially Lower Egypt, seems to be the first civilisation to have used large-scale beekeeping.

The importance of honey in Egypt can be seen in the way it appears in one myth at the very creation of the world by Re: ${ }^{5}$

The god Re wept, and the tears from his eyes fell to the ground and became a bee. The bee made his honeycomb and attended to the flowers of every plant: thus wax was created and honey from the tears of Re.

The bee is thus connected with primordial fertility, and it is in the rituals and cults of fertility and ithyphallic deities that honey plays an important part, and by extension in rites involving the after-life. This seems to have been particularly the case in Lower Egypt, where apiculture was especially wide-spread. Furthermore, the bee represents Lower Egypt in the royal title 'He of the reed and bee', and the same word is used of the red crown of the latter region. ${ }^{6}$

The following examples come from Ptolemaic Egypt, but they have nothing Greek about them. For instance, the statue of Min, the god of fertility and male potency, was covered in honey and he had temple bee-keepers and 'honey-hunters' (bityw). In scenes on the temple at Edfu, Ptolemy IV Philopator offers honey to the god, 'his father', and accompanying texts emphasise the beauty of the god and the way 'the goddesses rejoice at his phallus', which he himself also boasts about. ${ }^{7}$ In this scene fertility and kingship are thus united, the king and god in a filial relationship. There is a similar scene at Dendera, where the king in two crowns offers honey to ithyphallic Min-Re, who 'gives him the Two Lands': honey again ensures the king's authority. In another scene of a rite covered in secrecy, the fertilising power of honey is expressed in a different way: Ptolemy VIII Euergetes II Tryphon offers honey to the ithyphallic Manes Banebdjed, a deity also associated with Re, and the title says 'raising up the vase containing honey without knowing it, reviving the

3 What seems certainly to be honey is offered after the purification of the Temple of Bal in the Temple programme for the Babylonian New Year festival, along with other delicacies, aromatics and wine; the day ends with a rite at a pit in the Exalted Courtyard, where honey is offered as the king immolates a bull. Honey is used too when a temple is repaired, poured on the brickwork along with cream, milk, beer, wine, and good oil (ANET 340). I omit too the many examples of honey-cakes being offered to deities, which is a wide-spread phenomenon.

4 The earliest known honey comes from Georgia and is dated to c. 4300.

5 Papyrus Salt 825 II 5-7 (ed. Derchain 1965); c. 300 B.C.E. The use of honey in Egyptian rites has not been widely studied: see the small bibliography in Zecchi 1997: $71 \mathrm{n.2}$, and in general Moret 1902: 70-73, Laclant 1968, 1975; on technical matters Kuény 1950, Kritsky 2015; on Ptolemaic Egypt also Chouliara-Raïos 1989: 154-158.

6 See Zecchi 1997: 79-83.

7 See for the details Zecchi 1997: 72-74. 
phallus of the ejaculating bull' ${ }^{8}$ Similarly, in a further scene, Ptolemy IV Philopator offers ithyphallic Amon honey 'to make bright' 'the great eye' of Horus, ${ }^{9}$ and Amon gives him 'every circuit' of the two eyes. Also at Edfu Ptolemy IX Soter II gives honey, figs and wine to Thoth and the goddess Nehemet-awayt and the former gives him '[many fields] in the world with all kinds of sweet fruits', so it is not only regal power but the fertility that a good king should bring which is ensured by honey and other sweet gifts. The presence of Thoth, god of truth, also allows a link to be made here between honey and truth and justice. ${ }^{10}$

The important connection of honey with funerary rites and the after-life can be considered in the light of this association with fertility and health. It is used in tombs as offerings and food for the dead from the Old Kingdom onwards, as in the sealed pots of honey found in Tutankhamun's tomb. To begin with it seems to be associated only with kings and deities, but later with private individuals too. Rameses III gave large quantities of honey to the god Hapy, one of the 'Four Sons of Horus', who are found exclusively and ubiquitously in mortuary contexts: their heads formed the lids of canopic jars, and they mediated the movement of the dead to the after-life. ${ }^{11}$ The goddess Neith, a primordial goddess, 'father of fathers, mother of mothers', had a temple at Saïs which was called the 'House of the Bee': she too was involved with funerary rituals and, as a goddess of weaving, gave mummy-shrouds to the dead; in myth she guarded Osiris' coffin along with Isis and other deities. ${ }^{12}$

The way in which honey acts as a kind of revivifying material can be seen in the rituals to be carried out by the king at the temple of Osiris, god of the dead, dedicated by Seti I. ${ }^{13}$ Other gods were also associated with this cult of Osiris, including Amon, to whom the king has to say: ${ }^{14}$

\footnotetext{
Ah, Amon-Ra, lord of Karnak, I throw you honey, the eye of sweet Horus, secretion of the eye of $\mathrm{Ra}$, best of offerings and provisions... It is sweet to the heart of Amon-Ra, lord of Karnak, and beneficial on the day when Amon rests his heart on it; it opens his flesh, it puts in order his bones, it assembles his limbs, and Amon breathes in its perfume, just as Ra unites himself on the horizon.
}

The words recall the use of honey in embalming-fluid and the 'opening of the mouth' of the dead man: the anointing of the god with honey thus symbolically 'revives' him, as the sun rises again on the horizon. The revival recalls those of Min and Horus discussed above.

Honey can also actively protect against the malevolent forces of death, as in a magical spell to protect a child: ${ }^{15}$

You have come in the darkness, who have entered stealthily - his nose turned backwards, his face averted (i.e. the dead)... I will not let you take it away from me. I have ensured its protection against you with

See Zecchi 1997: 76-77.

More than half of some 900 Egyptian medicinal recipes contain honey, which though primarily consisting of sugar and water contains about 200 substances, including amino acids, vitamins, minerals and enzymes. See Zecchi 1997: 79-82.

See Heerma van Voss 1980, Dodson 2001.

See Schlichting 1980, Simon 2001.

See Moret 1902: 70-77.

Borghouts 1978: $§ 20$ (Papyrus Berlin 3027).

Borghouts 1978: $§ 65$. 
clover — that means, use of force, — with garlic — which harms you —, with honey — sweet to the people, but bitter to those-there (i.e. the dead).

In these examples honey, the primordial substance of fertility, not only displays fertilising, healing and protective powers, but also ensures a close reciprocal relationship between the power and merits of the king and that of the gods, especially those associated with the Sungod Re, the ultimate source of honey. The gods may give the king his power, fertility to his fields, truth and justice, but through gifts of honey the king also appears to revive the powers, sexual and other, of the gods.

\section{Hatti}

Honey and to some extent the bee thus played a highly significant role in the rites of Lower Egypt, but the situation is almost the opposite in Hurro-Hittite religion. ${ }^{16}$ In Hittite ritual and mythical texts ${ }^{17}$ honey (milit-, Luwian mallit-, Sumerogram LÀL) not only does not have the same central importance as in Egypt, but is found less frequently than say wine and oil with which it is often combined. Rather, it features in myth and ritual as one of a number of substances which are combined to achieve a particular aim, especially the appeasing and bringing back of gods who have disappeared in dudgeon or for some other reason. This is well exemplified in the appeal made to Telipinu: "just as honey (milit-) is sweet ... so let the soul of Telipinu become sweet (miliddu-) in the same way'. ${ }^{18}$

Why honey is so much less important is uncertain. That bee-keeping and honey was a feature of Hittite culture from early times is suggested by Law $92,{ }^{19}$ which contrasts the later, financial penalties for stealing hives with the earlier more brutally physical ones: ${ }^{20}$ 'if anyone steals two or three bee hives, formerly (the offender) would have been exposed to bee-sting. But now he shall pay six shekels of silver'. However one would not expect beekeeping to have had much of a place amongst nomadic Indo-European peoples, unlike in a settled country like Egypt, and it does not seem to have been so economically important as in Lower Egypt. This may explain too why, though the bee has close connections with mother-goddesses, ${ }^{21}$ and in one place bees are called 'children of the Sun-God', ${ }^{22}$ honey does not have the same kind of very close relationship with a deity suggested by the Lower Egyptian myth of the tears of Re.

When deities disappear and devastation hits the world, and gods and eagles have

16 On the Hittite use of honey, see in primis Haas 2003: passim but especially 497-502, Akkaya and Alkan 2007, also Hoffner 1974: 123-124.

17 For texts, translations and commentaries on Hittite texts see https://www.hethport.uniwuerzburg.de/HPM/index-en.php.

18 Hoffner 1998: no. 2 version 1, §14 (CTH 324.1 §22”.143-145). One might compare the Chinese custom of anointing the lips of the Kitchen God Zao Jun's statue with honey to 'sweeten' his words before he goes to heaven to inform the Jade Emperor about the family's behaviour that year.

19 For text and translation see Hoffner 1997: 91, also Haase 2001: 124-128.

20 On this shift which is found in a number of the laws see Hoffner 1997: 5-8. The only specific reference to honey in the Laws gives the price of a bottle as one shekel (Hoffner 1997: 144, Law 181 (13)).

21 See Haas 1981: 112-113; also Haas 2003: 497-498.

22 See Haas 2003: 497. 
failed to find the god, it is a bee which, often sent by the Mother Goddess Hannahanna, ${ }^{23}$ succeeds in finding the deity and aiding in his or her return. ${ }^{24}$ As we shall see, honey is one of the substances used in ritual to attract gods, but it is not clear that that is why a bee is sent. In a myth about the disappearance of an unknown god, the bee is told: 'O ... (?) [bee], you hold honey in your heart. So you should search the high mountains' ${ }^{25}$ but the honey may there indicate the bee's stamina rather than the importance of honey: in version 3 of the Telipinu myth, the bee nearly runs out of energy, 'the honey was exhausted [in its ...]. But it found him...' (§2). ${ }^{26}$ Furthermore honey is not itself used in rousing Telipinu, as the bee performs its task in a more robust way and uses wax: ${ }^{27}$ Hannahanna tells it, "when you find him, sting his hands and feet and make him stand up. Then take wax and wipe him off. Then purify him and make him holy again. Then conduct him back here to me'. ${ }^{28}$ In the same way, on the disappearance of the Hattic goddess Inara, the bee brings a hunting-bag of good things, not including honey, to tempt her and is told to use wax to soothe her. ${ }^{29}$ It is at this point that Telipinu is told to become sweet like honey and mild like ghee (see above), but again honey is only one of a number of substances used to attract him back. ${ }^{30}$

This idea of appeasement also figures in a human context in the very long and elaborate Hittite Funerary Ritual sallis wastais, 'Great Misfortune', referring to the king's death. ${ }^{31}$ It occurs in the rite of 'conciliation' (li-la), where the bones of the king are taken to the 'stone-house': 32

\begin{abstract}
They include the conciliation in his stone-house. With .... Yet again oily loaves of one-half upnumeasure, tarnaš-measure of honey, ... right thigh likewise. They arrange it alongside the soldier loaf. They wrap ... and carry them into the stone-house, ... in what inner chamber they have placed the bones. They dig the ground. One h.-vessel ... They pour ... into the h-vessel the honey ... They have held a figurine for conciliation... They have held ... for conciliation.
\end{abstract}

Much emphasis is laid at this point on the notion of conciliating the king's spirit: the honey is thus used at an important moment to placate the death king's soul, but apart from one other unplaced fragment this is the only reference to it in the evidence. ${ }^{33}$

The most prominent role played by honey is found in the Evocatio ritual aimed at

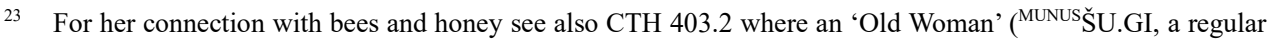
designation for one who carries out such rituals) with the Luwian name Malidunna 'Lady Honey' performs a ritual concerning her, but honey is not mentioned in the surviving text; see Haas 2003: 19.

24 See Hoffner 1998: no. 2 version 1 §7 (CTH 324.1 §9'.75); version 2 §5 (CTH 324.2 §5); version 3 §§1-2 (CTH 324.3 §1-2; all Telipinu); no. 3 \$13 (CTH 325 \$13.115-9; Storm God); no. 9a (CTH 336.1 §8'.36; Inara); no. $13 \mathrm{~b} \S 3$ (CTH $335.2 \S 3$ '.26-7; unknown god). Cf. also no. $11 \S 1$ (CTH 457.7.1 $11.8-18$; the immortal human soul), where the bee brings requisite objects. On the connection of the bee with Hannahanna and other mother goddesses in the Near East and Greece see Haas 1981: 113-116.

Hoffner 1998: no. 13b $\$ 3$ (CTH 335.2 §3'.26-27).

Hoffner 1998: no. 2 version $3 \S 2$ (CTH $324.3 \$ 3.15-16)$.

On the ritual use of wax see Haas 2003: 498-9.

Hoffner 1998: no. 2 version $2 \S 5$ (CTH 324.2 §5'.30-37).

Hoffner 1998: no. 9 (CTH 336).

Compare the use of honey alongside flour, bread, cheese, fruit, rennet and salt in the placating of the thundering Storm God (Hoffner 1998: no. $12 \S 4$ (CTH 727)).

CTH 450; see Kassian et al. 2002.

Day 3, Rs.10-19 (Kassian et al. 2002: 281).

Indeterminate fragment 2 IV 6 (Kassian et al. 2002: 669). 
the Cedar Gods. ${ }^{34}$ The absence of the gods is imagined as being caused by someone, foreigner or Hittite, having lured them away (i 66-72) or by their absence in 'the enemy country [and] evil uncleanliness' (ii 5). The rite is used 'when the diviners attract the god by means of nine trails from the meadows, the mountains and the rivers from the sea, from the springs, from fire, from heaven and from the earth' (i 1-2). The celebrants go out of the city to a road and a wickerwork table is set up with a basket on it and a fireplace in front.

They draw a length of cloth down from the wickerwork table and make it into a trail. Then they draw a trail in fine flour in front of the cloth; on the one side of the flour trail they draw a trail in honey, but on the other side they draw a trail in wine and fine oil mixed together. [Various food-stuffs are added to the trails which symbolise an obstacle-free path for the gods. A diviner prays:] 'Let the vigorous Cedar-gods eat and drink the trails! Let them satisfy their hunger and quench their thirst'.

(§§ i 22-5, 48-9)

As in the appeals to Telipinu and the Storm God the food-stuffs offered have a symbolic function: 'just as this fine oil is soothing ... even so let the king and queen of Hatti land be agreeable to the gods' (ii 29-32). Honey is then, with wine, fine oil, bread and fruits, poured out at the feet of the gods' statues to tempt them in. ${ }^{35}$

Similar techniques are used to summon deities from the underworld, ${ }^{36}$ but with the symbolic differences that they tend to take place in darkness or at dawn not in broad daylight and, instead of putting the offerings at the feet of the gods' statues, a pit is specially dug and foodstuffs and other offerings including honey are put down into it.

A good example is the Kizzuwatnean Relocation of the Temple of the Goddess of the Night. ${ }^{37}$ On the second day, at the pits called api, for the 'ritual of the blood' they take amongst other items $(\S 12)$

two mulati breads-a half-handful, a small cheese, a little fine oil, a half-handful of vegetable oil, a half-handful of honey, one and a half handfuls of clarified butter, a wakšur measure of wine, a lamb or a goat.

The following dawn, 'the šankunni-priest calls the goddess from the āpi pits seven times' $(\S 13) .^{38}$

Finally, in this category honey has its place in a prayer and ritual not aimed at actually attracting gods but preparing the way for the king to lay before them the problems he faces.

34 I quote $A N E T$ 351-3 as CTH 483 is not yet edited and translated in Hethport; see Haas 2003: 96-97, and 94 97 on such rituals of attraction. I am grateful to Christopher Metcalf for help on this passage.

35 For a similar procedure inviting the gods of an enemy town along nine paths each of oil, honey and porridge see CTH 423 §3”.20-21; also $484 \S 4.31$ (Fates and Mother Goddesses; see Haas 2003: 94-95, 501), 631 Rev.1'-7' (?Storm God) and 670 Rev. 15'-19' (Storm God; on these last two see Barsacchi 2016).

36 There are similar rites in Akkadian and Sumerian sources: see Hoffner 1967.

37 CTH 481; Mouton 2016: 334-373.

38 For another example of the putting of honey with other substances into the api pits, cf. the Incantation of Infernal Deities (KUB VII 41++, iii 13; see Hoffner 1967: 391); in CTH $484 \$ 4.31$ et al. honey provides one of the paths along which the Fates and Mother Goddesses are to travel having come out of the pits (72ff.). Honey does not however appear in the summoning of Ishtar in CTH 716 (see Hoffner 1967: 391-392), nor of the Storm God of Nerik (Hoffner 1998 no. 4 (CTH 671). 


\title{
For instance, in a Rite Conducted in an Emergency, king Muwatalli states: ${ }^{39}$
}

\begin{abstract}
When things get too much for a man he sets before the gods his circumstances. On the roof, in the direction of the Sun-god, he sets up two offering-tables covered with wickerwork. He sets up one table for the Sun-goddess of Arinna, and one table for the male gods. Upon them there are found 35 loaves made of one handful of damp flour, a shallow bowl of honey and fine oil inside, a pot filled with a fat-cake, meal packed in a bowl, 30 pitchers of wine. When he has got all of this ready, the king ascends to the roof and bows before the Sun-god of Heaven.
\end{abstract}

Honey has its place among the generous offerings, but without standing out.

Honey is also found in apotropaic rituals, though again it is only one aspect and not a central feature. In a ritual performed to resolve a domestic quarrel involving sorcery within the family, ${ }^{40}$ a considerable number of items and animals are used to assume and remove the malediction. At one point, a black sheep is brought in, which The Old Woman (who officiates at the rite) waves over the participants and says: ${ }^{41}$

'For your heads and your complete person, the black lamb is the substitute. The maledictions are also behind its mouth and tongue!' She turns it above them. The two sponsors of the ritual spit in its mouth, then they slaughter the lamb. Then they dismember it. They make a hearth and burn it entirely. They pour over it honey and virgin olive oil. She breaks a big sweetened loaf and throws it in the hearth. She also makes a libation of wine.

Later she takes seven recipients of an uncertain nature and fills them with honey, wine, figs, raisins, a tendon, salt and fat, then shatters them, symbolically destroying the tongue and mouth that made the malediction ( $\S 34-5)$. These are however the only two uses of honey in a long and complicated rite and they do not occur at moments of particular significance.

Here the honey plays a minor role in the removal of the curse, but it can also be more central. In a rite against the malediction of Tudhaliya and his family by one Ziplantawiya tongues representing those which uttered the curse are made and the official prays: ${ }^{42}$

\footnotetext{
the evil and bewitching tongues which Ziplantawiya made we here have presented in honey: SunGod of Blood and Weather-God be appeased! May these evil and bewitched tongues leave my lord, his wife, his sons and his house.
}

Honey thus functions in a manner reminiscent of the way it was used to 'sweeten' the temper of disaffected gods discussed above: the evil tongues are transformed and the gods appeased by the honey.

The apotropaic quality of honey is also clear in a cleansing rite of the city of Šamuha. Various 'sympathetic' rites are carried out, and finally a basin is dug with a channel to the river: ${ }^{43}$

into it they put a boat made(?) of a little silver and gold. They also make small 'oaths' and 'curses'

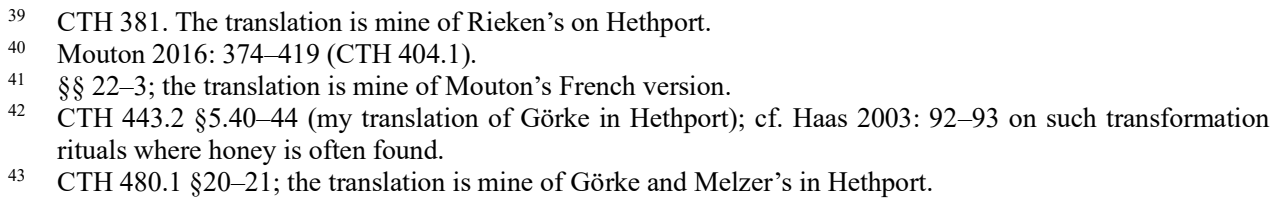


of silver and gold and put them into the boat. Then the ditch which empties the basin carries the ship from the basin into the river. Afterwards, he pours out a little fine oil and honey and while doing so speaks as follows: 'Just as the river has carried away the ship and no trace of it can be found any more-whoever has uttered an evil word, perjury, curse or uncleanliness in the presence of their god - even so let the river carry them away! ... See! I have poured out fine oil and honey after them. The trail behind them is anointed with fine oil and honey. Let the evil word be turned away to beyond.

Here the honey functions in a way similar to that in the Egyptian spell discussed above: what attracts the good deities is anathema to the bad and to perjury, curses etc.

Though honey plays a regular role in these rituals, that role must not be overemphasised: it is just one among many attractive foodstuffs which will bring the arrival of the desired god or gods.

\section{Greece}

\subsection{Mycenean Greece}

Honey (Myc. me-ri) was a valued commodity in the Bronze Age Aegean, ${ }^{44}$ and was a major element of offerings and festivals especially in Mycenean Knossos, ${ }^{45}$ where we hear of melidamarte(s) ('superintendents of honey'), who may have had religious functions. Unfortunately, there is not a great deal of evidence about which gods it was offered to, the rituals or the guise in which they may have received it.

Tablet 702 from the series of tablets from Knossos Gg (1), ${ }^{46}$ which seems to be part of a calendar, records 'one amphora of honey for all the gods / one amphora of honey for the Mistress of the Labyrinth', ${ }^{47} \mathrm{Gg}$ (3) 705 records one for Eleuthia (e-r-u-ti-ja; cf. Cretan Eleuth(i)a), the goddess of child-birth associated with Amnisos on Crete's northern shore, and for all the gods; and 717 one for the gods and ]si-da-o-ne, usually restored to e-ne-sida-on-e, Poseidon in his chthonic aspect as 'Earthshaker' (later Greek Ennosigaios). ${ }^{48}$ At Chania, a single tablet, $\mathrm{Gq} 5$, records that Zeus receives an amphora of honey and Dionysus two at Zeus' shrine.$^{49}$ Finally, 19 litres of honey appear on tablet Un 02 which may relate to a royal initiation: the quantities of all the items are enormous (1574 litres of barley, 26 rams, for instance), so provisions rather than offerings may be meant, though both may have been be involved.

From this scarce evidence it is hard to draw any conclusions about Mycenean usage of honey. The list of gods does not reveal anything in detail about the kind of gods to whom it was offered: the reference to the sacrifice to 'all the gods' need not suggest that any god

\footnotetext{
See e.g. Melas 1999.

On honey in Mycenean locations see esp. Weilhartner 2005, Bendall 2007: 140-152.

On the Gg tablets see Weilhartner 2002-2003, Bendall 2003: 140-143.

This translation is not entirely certain. The tablet reads $d a-p u_{2}-r i-t o-j o:$ an $l / d$ alternation can be paralleled in Greek in laphne / daphne, but it would be unusual; see Ventris and Chadwick 1973: 310, 475.

48 See Ventris and Chadwick 1973: 204-206. Poseidon may also receive honey (possibly in an aromatic form) in a list of contributions made by 'Sarapeda' (a tract of land?) at Pylos (Un 718), but honey is not certainly involved: see Ventris and Chadwick 2003: 171. On the Fs series, which may possibly record offerings of honey to local deities, see Weilhartner 2002-2003.

49 Bendall 2007: 149-150. The evidence for Pylos is very uncertain (Bendall 2007: 150-152).
} 
could get honey, since offerings 'to all the gods' are a feature of Knossos ritual (and indeed are found in later times). Nor can we say anything about the kind of rites honey was used in.

\subsection{Homer, Archaic and Classical Greece}

Honey appears in ritual contexts in Homer in three places. ${ }^{50}$ Twice it is used in burning on a pyre: when Achilles conducts Patroclus' burial, he leans against the bier set upon the pyre 'amphoras of honey and unguent', ${ }^{51}$ and Agamemnon tells Achilles in the Underworld that 'you were burned in the clothes of the gods and with much unguent and sweet honey'. ${ }^{52}$ This accords with the archaeological evidence: such vessels are found in Proto-Geometric cremations. ${ }^{53}$

More significantly for our comparison, when Odysseus is instructed on how to make contact with the ghost of the seer Teiresias in the Underworld, Calypso advises him as follows: ${ }^{54}$

dig a pit a cubit's length this way and that, and in it pour a libation to all the dead, first of milk and
honey (melikraton), then of sweet wine, and thirdly of water; sprinkle on them white barley meal...
But when you entreat with prayers the glorious tribes of the dead, then sacrifice a ram and a black ewe,
turning their heads toward Erebus but turn yourself backward and look towards the streams of the river.

What is striking here is the similarity to the Hittite pit-rituals we discussed above. In the Kizzuwatnean Relocation of the Temple of the Goddess of the Night and the Incantation of Infernal Deities honey was used to summon the deities from the api pits. ${ }^{55}$ In the ritual summoning the Former Gods honey is not involved, but a pit is dug into which the blood of a lamb is poured, followed by oil, beer, wine and cereals. The Sun-goddess of the Earth is invoked to send the gods up, which include a seer Aduntarri, who will enjoy the offerings. ${ }^{56}$

The Hittite influence on this Odyssean passage is clear, ${ }^{57}$ but at the same time it prefigures a distinctive feature of Archaic and Classical Greek religion, which is very different from what we have seen so far, whereby honey was generally offered in contexts of death and the Underworld: it is not usually offered to the Olympian gods, except in their guises as gods of the Underworld, but to heroes and other deities with such 'chthonic' connections. ${ }^{58}$ Honey, pure or mixed with water or milk, and unmixed wine, water and oil ${ }^{59}$ formed the nepphalia 'wineless libations' usually proper to such figures ${ }^{60}$ and were seen to

Other references are Il. 1.249, 11.631, 18.109, Od. 10.234, 20.69.

Il. 23.170 .

Od. 24.67.

3 See Andronikos 1968: 92-93, Kurtz and Boardman 1971: 74; on drink-offerings to the dead generally see Stengel 1910: 183-186.

Od. $10.517-20,526-529$.

See n.37 and n.3 for Mesopotamian parallels.

CTH 446; see Otten 1961, also West 1997: 426-427. In CTH 409 a black lamb is used.

On the question of how far the Hittite sallis wastais rite may have influenced the burial of Patroclus in Il. 23 see Rutherford 2007.

58 On the use of honey and oil, water and unmixed wine in 'abnormal' rites see especially Graf 1981; on Greece generally also Usener 1902, Schuster 1931: esp. 364-366, Ziehen 1934, Detienne 1971.

59 On oil in classical antiquity see Bowie 1993.

60 See Henrichs 1984. 
be the opposite of normal libations of wine. ${ }^{61}$ Empedocles and Theophrastus saw such offerings and the absence of wine as characteristic of earlier times,${ }^{62}$ and as is well known milk and honey were seen as characteristic of the Golden Age. ${ }^{63}$ They are attributed (milk more so than honey) also to marginal races, ${ }^{64}$ and also to the Pythagoreans. ${ }^{65}$

The chthonic connections of honey in Greece can be seen from its particular association with the goddess Demeter, and especially with rites connected with the return of her daughter Persephone from the Underworld after her rape by Hades. Indeed, women dedicated to the rites of Demeter were called Melissai 'bees'. ${ }^{66}$ Thus Pausanias in his tour of Greece describes a sacrifice, made outside a cave on Mount Elaeus in Arcadia, to Demeter the Black, so named because she donned sombre clothes on the rape of Persephone and hid herself there: ${ }^{67}$

\begin{abstract}
I sacrificed nothing to the goddess, which is the custom of the natives. But it is the custom for private

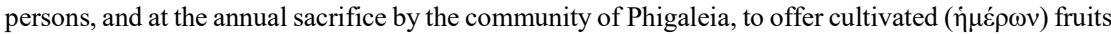

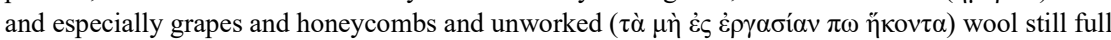
of its grease, which they place on the altar built before the cave, and when they have put them there they pour oil over them.
\end{abstract}

Unlike in a 'standard' sacrifice, the offerings are vegetable not animal, honey and wool are offered in their natural states, and unprocessed grapes but not wine are used. The use of such offerings is very common in Greece to mark abnormal periods, such as here of the withdrawal of the goddess in charge of agricultural fertility.

The myth of Persephone's abduction and rebirth was also the central myth of the Thesmophoria festival, one of the most widely attested Greek rituals and recorded for thirty towns in Greece, Africa, Asia Minor, Italy and Sicily from the eighth century B.C.E. until the fourth century C.E. Thus, at this festival in the Attic deme of Cholargae, two kotulai of honey figured alongside various grains, fruits, seeds and cheese in offerings for Persephone's return: ${ }^{68}$ again, the offerings are natural products not domesticated animals, and wine is excluded.

In his rite in Hades, Odysseus offered honey to the ghosts in the Underworld, and this continues to be a regular feature of such rites: Atossa in Aechylus' Persae uses honey, milk, water, unmixed wine and oil to summon Darius. ${ }^{69}$ We saw the same in Hittite ritual but, though the use of a pit by Odysseus may be due to Anatolian influence, the prevalence

61 See Plut. Mor. 671C for the distinction; for melikraton see 464B, 671B, also Ziehen 1934.

62 Porph. Abst. $2.20=$ Emp. fr. 31 B 128 and Theophr. de pietate fr. 12 (for which see Pötscher 1964: 62-82, 105-106).

63 See Usener 1902.

64 E.g. the milk- and cheese-eating Cyclopes (Od. 12.219-23), the 'milk-drinking' Hippomolgoi ('Horsemilkers'; Il. 13.5-6), and the milk- and honey-eating Scythians (Trogus, ap. Justin. 2.2) and men in the Moon (Lucian, $V H$ 1.24).

65 D.L. 8.19.

66 See scholia to Pindar, Pyth. 4.106a (II 112.17-113.6 Dr.). In the story told there the Melissai got their name for persuading men to eat not meat, which mirrors the way that living on honey is often opposed to meateating in rituals. See also Guiman 2008: 157-169.

$67 \quad 8.42 .11$

$68 \quad$ IG II ${ }^{2} 1184.3-6,10-11$ (334/3 B.C.E.).

69 A. Pers. 611-617; cf. e.g. E. IT 159-165, Or. 115. 
of the use of honey in later Greek rites suggests this is a Greek feature.

Honey could not only summon figures from Hades but also ease the entry of ordinary mortals into Underworld contexts. For instance, at the shrine of Trophonius at Lebadeia in Boeotia those consulting the oracle had to undergo rites which Pausanias describes from personal experience: ${ }^{70}$

The shape of this structure is like that of a bread-oven... They have made no way of descent to the bottom, but when a man comes to Trophonius, they bring him a narrow, light ladder. After going down he finds a hole between the floor and the structure... The descender lies with his back on the ground, holding barley-cakes kneaded with honey, thrusts his feet into the hole and himself follows, trying hard to get his knees into the hole.

Once inside the answer to his question is given him by sight or hearing, and he miraculously comes out feet-first.

A more complex example is found in a Sacred Law from Selinous in Sicily, in which the Tritopatores, figures representing the ancestors of the people there, received an offering of melikraton, poured through the roof of an underground sanctuary: ${ }^{71}$

To Zeus Eumenes [and] the Eumenides sacrifice a full-grown (sheep), and to Zeus Meilichius in the
(plot) of Myskos a full-grown (sheep). (Sacrifice) to the Tritopatores, the impure, as (one sacrifices) to
the heroes, having poured a libation of wine down through the roof, and of the ninth parts burn one. Let
those to whom it is permitted perform sacrifice and consecrate, and having performed aspersion let them
perform the anointing, and then let them sacrifice a full-grown (sheep) to the pure (Tritopatores).
Pouring down a libation of honey mixture, (let him set out) both a table and a couch, and let him put on
(them) a pure cloth and crowns of olive and honey mixture in new cups and cakes and meat; and having
made offerings let them burn (them), and let them perform the anointing having put the cups in.

Here the Tritopatores to whom the honey is given are associated with Zeus in his chthonic guises as Meilichius, a word of uncertain origin but connected with meli by folk etymology, ${ }^{72}$ and Eumenes 'the Kindly One' and with the Furies, who live in the Underworld and are also given their similar euphemistic name. Involved too is a chthonic deity called Elasteros, who is probably connected with the Zeus Elasterus to whom honey is offered on Paros. ${ }^{73}$

Like the Trophonius rite this one involves underground chambers, but it also displays features which contrast with more 'normal' sacrifices. The libations are not poured on the ground or on the offerings but into pits, and the burning of the offerings and apparently the table and couches is unusual. ${ }^{74}$ These abnormal features can sometimes be found in the same ritual, distinguishing its different parts. On Cos at the festival of Zeus Polius an ox was brought in to be sacrificed to him, but before that happened a rite was performed to Hestia

9.39.10-11.

Jameson et al. 1993: 15 (A8-16).

Cf. $\mu \varepsilon \imath \lambda \imath \chi i \omega v \pi 0 \tau \tilde{\omega} v$ in S. $O C 159$, explained by the ancient commentators as referring to honey mixed in the drink-offerings.

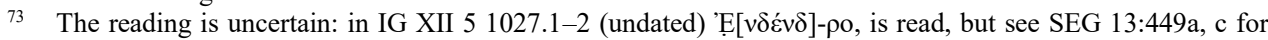
'E[ $[\lambda \alpha \sigma \tau \dot{\varepsilon}]-\rho o$.

74 See Jameson et al. 1993: 30-31, who also record a late-Archaic hypogeum dedicated to Hera at PaestumPoseidonia in which six bronze vessels filled with honey were discovered. 
Hetaereia in which again unusual actions were carried out. ${ }^{75}$ The priest poured a libation of mixed wine before the bull and the Hestia rite began with a phyllobolia (throwing of leaves), an archaic rite involving a natural product in contrast to the normal throwing of cultivated

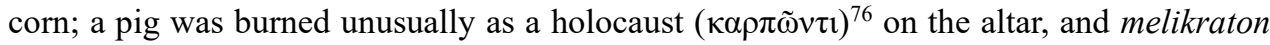
was poured over it and the splankhna; the entera are washed and burnt by the altar 'without libation' ( $\alpha$ ( $\pi \mathrm{o} \tau \alpha)$, then melikraton is poured on the fire. After all this the feast of Zeus Polius is announced and a libation first of unmixed then mixed wine is made. The transitions into and out of the 'abnormal' rite for Hestia are thus marked by offerings of mixed wine, which frame a rite where honey and neat wine are used.

If honey can distinguish different parts of a ritual it can also mark a distinction between deities. For instance, on Delos the birth-goddess Eleithuia is given a variety of foods including honey, ${ }^{77}$ but Poseidon, whose rites are described before these and involve a number of different offerings, does not. The goddess of the margins has honey, but not the major Olympian god of the sea. Similarly heroes receive honey but not gods in their Olympian guises. For instance Heracles is the heroic figure par excellence, and he is in receipt of a honey-offering on Cos: after a bull has been sacrificed, barley, wheat, ewes' cheese and four kotulai of honey are offered to him. ${ }^{78}$

There are cases where the Olympians in their guise as Olympians do receive an offering involving honey, but they are very rare. ${ }^{79}$ In Miletus, Dionysus, Hera, Zeus, Leukos (a hero?) and Apollo together receive offerings, but it is only Dionysus, as far as the text allows us to see, who gets honey (along with a male sheep, an ecteus of grain, an ekte of wine, wood and unguent). ${ }^{80}$ If he was the only one, we do not know why. Closer to the normal pattern is a rite in Elis: ${ }^{81}$

each month the Eleans sacrifice once on all the altars I have enumerated. They sacrifice in an ancient

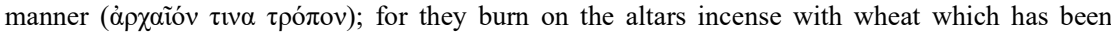
kneaded with honey, placing also on the altars twigs of olive, and using wine for a libation.

Again, this unusual sacrifice avoids animal offerings and employs natural foodstuffs and plants, but it is notable that this rite is specifically described as 'archaic', these offerings being characteristic of earlier or even Golden Age life, as we have seen.

Finally, moving to later times, honey can feature significantly in imported cults. In the cult of Mithras, in the initiation into the 'Lion' and 'Persian' grades, Porphyry records that: ${ }^{82}$

75 IG XII 4.1.278.33-36 (= Sokolowski 1969: no. 151 A 27-44; mid $4^{\text {th }}$ century B.C.E.): this is the subject of Graf 1981.

76 On the meaning of this word see Sokolowski 1969: 256 on 11. 31-32.

77 ID 401.23 (c. 190 B.C.E.); cf. also 440 A 70 (179 B.C.E.), 445.4 (178 B.C.E.), 464.14 (c. 170 B.C.E.). In Paus. 6.20.2 she shares a shrine where honey-cakes are offered to a snake-divinity (Ventris and Chadwick 1973: 310 are inaccurate on this).

78 Iscr. di Cos ED 140 ( $4^{\text {th }}$ cent. B.C.E. $)$.

79 I base this on a search of PHI. There are of course many places where $\mu \varepsilon \lambda t$ appears where we can say nothing about the context, deity or ritual.

$80 \quad$ 204.4, 11 McCabe 1984 (= Sokolowski 1955: no. 41 A; 525-500 B.C.E.)

81 Paus. 5.15.10.

82 On the Cave of the Nymphs, 15 (tr. Geden and Ronan 1990). 


\begin{abstract}
the votaries use honey for many and diverse symbolic purposes, because of its variety of properties, since it possesses both purgative and preserving virtue. For by honey many things are preserved from corruption and wounds of long standing are cleansed. It is also sweet to the taste and is gathered from flowers by bees which are regarded as born of cattle. When therefore into the hands of those initiated into the lion grade honey is poured for washing instead of water, they are charged to keep their hands clean from all wrong and injury and defilement; the offering of actual water to the initiate is avoided as being hostile to the fire with its purifying qualities. The tongue also is purified from all sin by honey. And when honey is offered to the Persian as the guardian of the fruits, its preservative virtue is symbolically expressed.
\end{abstract}

Here the ritual, medicinal and purificatory aspects of honey which we have discussed are seen in their full array.

\title{
4. Summary
}

Where then does this leave us? In a way, the article shows the problems of focussing on a single substance. To understand the uses of honey, especially in Hatti and among the Greeks, one needs to see how it operates with other substances in order to get a fuller picture of its significances: in Greece its close connection with oil, water and unmixed wine makes clearer its meaning in a ritual and in Greek religious thinking. ${ }^{83} \mathrm{~A}$ further problem is that the paucity of evidence in all three cultures means one has rather to neglect chronology and run together pieces from very different periods. This is a particular problem with the question concerning Greece to be discussed below.

On the other hand, very striking differences have been shown between the three countries: in Lower Egypt (but much less so in Upper) honey clearly plays a major role in important royal rites involving kingly authority, the reciprocal relationship between king and gods and the fertility of the kingdom; in Hatti it is less prominent but its principal uses are to attract beneficial deities of the Underworld and heaven by 'sweetening' them and to dispel curses; in classical Greece there is the perhaps surprising restriction of its use to rites to do with the dead, to the deities of the Underworld and to festivals involving unusual rituals or evoking the ancient past.

The reasons for these differences are not easy to determine. In Lower Egypt the presence of the bee in the royal title and its sharing a word with the crown, alongside the ritual importance of honey, must be related in some way to the long-standing economic and social importance of bee-keeping in that area. By contrast, the fact that the Hittites seem to have settled in their lands only around 1650 B.C.E. may mean that bee-keeping did not have time to achieve the importance it had in Lower Egypt. ${ }^{84}$

Perhaps the most striking feature of the Greek use of honey is the difference that seems to have grown up between Mycenean Greece and later, in that, from the very limited evidence we have for the Mycenean period, there does not seem to have been the distinction found later whereby honey was largely reserved for deities other than the Olympians or for Olympians in their chthonic guises. In Knossos and Chania Zeus, Dionysus and probably

\footnotetext{
As demonstrated by Graf 1981.

On the complex question of the settlement of Bronze Age Anatolia see Brice 2005: 8-20.
} 
Poseidon Ennosigaios, 'Olympian' deities at least for later Greeks (though as Ennosigaios Poseidon may have a chthonic aspect here), receive honey, alongside the goddess of childbirth Eleuthia and the enigmatic Mistress of the Labyrinth. Of these only Zeus in his chthonic guise, Dionysus and Eleuth(er)ia receive honey in the later period: Poseidon never does in any guise.

If there was a change it very likely took place in the period after the collapse of the Mycenean and other states around 1200 B.C.E. One possibility (and it is no more than that) is that it was associated with the rise of 'hero' cults, that is cults of great individuals whose exploits in diverse areas led to their being considered as divine figures. They were distinguished from the Olympian gods as being effective locally rather than universally, and occupying places under the ground rather than in heaven. This distinction was also made by the general practice of offering heroes black victims in contrast to the white ones given the Olympians, and doing so on altars that were flat as opposed to the raised altars of the Olympians. ${ }^{85}$ It may be therefore that honey, like unmixed wine, wineless sacrifices and other natural products, was chosen as the distinguishing offerings for the new deities. New cults demanded new rites and ones that would distinguish them from the rites of other gods. There may have been a political dimension to all this at a time of rapid political and social change: were heroes used to legitimise new political groupings and organisations, so new rites were established by new authorities? Honey would thus have moved from a substance with important roles in a number of rituals to more specific areas in archaic and classical Greece. We shall probably never know.

\section{REFERENCES:}

ANET J.B. Pritchard (ed.), Ancient Near Eastern Texts relating to the Old Testament,

CTH ed. 3, Princeton: Princeton University Press, 1969.

Hethport https://www.hethport.uni-wuerzburg.de/HPM/index.php.

ID Inscriptions de Délos, 7 vols., Paris: H. Champion, 1926-1972.

Iscr. di Cos $\quad$ M. Segre (ed.), Iscrizioni di Cos, Rome: 'L'Erma' di Bretschneider, 1993.

KBo Keilschrifttexte aus Boghazköi.

KUB Keilschrifturkunden aus Boghazköi.

PHI https://epigraphy.packhum.org/.

Akkaya, H. and Alkan, S. 'Beekeeping in Anatolia from the Hittites to the Present Day', Journal of Apicultural Research, 46, 2007, 120-124.

Andronikos, M. Totenkult. Archaeologia Homerica III W, Göttingen: Vandenhoeck and Ruprecht, 1968.

Barsacchi, F.G. 'KBo 20.64: A Hittite Invocation Ritual Mentioning the Thunder', Altorientalische Forschungen, 43, 2016, 1-16.

Bendall, L.M. Economics of Religion in the Mycenaean World: resources dedicated to religion in the Mycenaean palace economy, Oxford: Oxford University Press, 2007.

Borghouts, J.F. Ancient Egyptian Magical Texts, Leiden: Brill, 1978.

85 The distinction is not absolute: see generally Scullion 1994. 
Bowie, A.M. 'Oil in Ancient Greece and Rome', in: M. Dudley and G. Rowell (eds.), The Oil of Gladness: anointing in the Christian tradition, Collegeville, Minn.: Liturgical Press, 1993, $26-34$.

Bryce, T, The Kingdom of the Hittites, Oxford: Oxford University Press, 2005.

Chauvin, R. (ed.) Traité de biologie de l'abeille: vol. 5 Histoire, ethnographie et folklore, Paris: Masson et $C^{\text {ie }}, 1968$.

Chouliara-Raïos, H. L'abeille et le miel en Égypte d'après les papyrus grecs, Ioannina: Panepistemio Ioanninon, 1989.

Crane, E. 'History of Honey', in: Crane 1975: 438-488.

. (ed.) Honey: a comprehensive survey, London: Heinemann, 1975.

Derchain, P. Le Papyrus Salt 825 (BM 10051), rituel pour la conservation de la vie en Égypte, Brussels: Palais des académies, 1965.

Detienne, M. 'Orphée au miel', Quaderni urbinai di cultura classica, 12, 1971, 7-23.

Dodson, A. s.v. 'Four Sons of Horus', in: Redford 2001.

Geden, A. S. and Ronan, S. Mithraic Sources in English, Hastings: Chthonios Books, 1990.

Gilan, A. 'The Ewe that was a Scapegoat Bride: a new look at the Hittite Bestiality Purification Ritual KUB 41, 11+', Zeitschrift für Assyriologie und vorderasiatische Archäologie, 108, 2018, 226-234.

Graf, F. 'Milch, Honig, Wein', in: Perennitas: studi in onore di Angelo Brelich, Rome: Edizioni dell'Ateneo, 1981, 209-221.

Guiman, M. Melissa: archeologia delle api e del miele nella Grecia antica, Roma: Giorgio Bretchneider editore, 2008.

Haas, V. Magie und Mythen im Reich der Hethiter, vol. 1, Vegetationsmythen und Pflanzenmagie, Hamberg: Merlin, 1977.

. 'Leopard und Biene im Kulte 'hethitischer' Göttinnen: Betrachtungen zu Kontinuität und Verbreitung altkleinasiatischer und nordsyrischer religiöser Vorstellungen', UgaritForschungen 13, 1981, 101-116.

. Materia Magica et Medica Hethitica: Ein Beitrag zur Heilkunde im Alten Orient (unter Mitwirkung von D. Bawanypeck), vol. 1, Berlin/New York: de Gruyter, 2003.

Haase, R. 'Über Bienen und Schafe in der Hethitischen Rechtssatzung', Altorientalische Forschungen 28, 2001, 124-131.

Henrichs, A. 'The Eumenides and Wineless Libations in the Derveni Papyrus', Atti del xvii congresso internazionale di papirologia, Naples: Centro internazionale per lo studio dei papiri ercolanesi, vol. 2, 1984, 255-268.

Heerma van Voss, M. 'Horuskinder', in: Lexikon der Ägyptologie, Wiesbaden: Harrassowitz, vol. 3, $1980,52-53$.

Hoffner, H.A. 'Second Millennium Antecedents to the Hebrew 'Ôb', Journal of Biblical Literature, 86, 1967, 385-401.

. Alimenta Hethaeorum: food production in Hittite Asia Minor, New Haven: American Oriental Society, 1974.

. The Laws of the Hittites: a critical edition, Leiden, New York and Cologne: Brill, 1997.

Jameson, M.H., Jordon, D.R. and Kotansky, R.D. A Lex Sacra from Selinous, Durham, NC: Duke University Press, 1993.

Kassian, A., Korolëv, A., and Sidel'tsev, A. (eds.) Hittite Funerary Ritual šalliš waštaiš, Munster: Ugarit Verlag, 2002.

Kelhoffer, J.A. 'John the Baptist's 'Wild Honey' and 'Honey' in Antiquity', Greek, Roman, and Byzantine Studies 45, 2005, 59-73.

Kritsky, G. The Tears of Re: beekeeping in ancient Egypt, New York: Oxford University Press, 2015.

Kuény, G. 'Scènes apicoles dans l'ancienne Égypte', Journal of Near Eastern Studies, 9, 1950, 84-93.

Kurtz, D.C. and Boardman, J. Greek Burial Customs, London: Thames and Hudson, 1971. 
Le Sage, D.E. ‘The Language of Honey', in: Crane 1975: 426-438.

Leclant, J. 'L'abeille et le miel dans l'Égypte pharaonique', in: Chauvin 1968: 51-60. . 'Biene', in: Lexikon der Ägyptologie, vol. 1, Wiesbaden: Harrassowitz, 1975, 786-789.

McCabe, D.F. Miletos Inscriptions: texts and list, Princeton: Princeton University Press, 1984.

Melas, M. 'The Ethnography of Minoan and Mycenaean Beekeeping', in: P.P. Betancourt, V. Karageorghis, R. Laffineur, and W.D. Niemeier (eds.) Meletemata: studies in Aegean archaeology presented to Malcolm H. Wiener, vol. 2, Liège/Austin: Université de Liège Press/University of Texas at Austin Press, 1999, 485-491.

Moret, A. Le rituel du culte divin journalier en Égypte, d'après les papyrus de Berlin et les textes du temple de Séti $1^{\mathrm{er}}$, à Abydos, Paris: E. Leroue, 1902.

Mouton, A. Mythes, rites et prières Hittites, Paris: Les Éditions du Cerf, 2016.

Otten, H. 'Eine Beschwörung der Unterirdischen aus Boğazköy', Zeitschrift für Assyriologie und vorderasiatische Archäologie, 54, 1961, 114-157.

Pötscher, W. Theophrastos ПEPI EY EEBEIAL, Leiden: Brill, 1964.

Redford, D.B. (ed.), Oxford Encyclopedia of Ancient Egypt, Oxford: Oxford University Press, 2001.

Rutherford, I.C. 'Achilles and the šalliš waštaiš ritual: performing death in Greece and Anatolia', in: N. Lanieri (ed.), Performing Death: social analyses of funerary traditions in the ancient Near East and Mediterranean, Chicago: Oriental Institute of the University of Chicago, 2007.

Schlichting, R. 'Neit', in: Lexikon der Ägyptologie, Wiesbaden: Harrassowitz, vol. 4, 1980, 392-394.

Schuster, M. 'Mel', in: Real-Encyclopädie der classischen Altertumswissenschaft, J. B. Metzlersche Verlagsbuchhandlung, 15, 1931, 364-384.

Scullion, J.S. 'Olympian and Chthonian', Classical Antiquity 13, 1994, 75-119.

Sokolowski, F. Lois sacrées de l'Asie mineur, Paris: E. de Boccard, 1955. . Lois sacrées des cités grecques, Paris: E. de Boccard, 1969.

Simon, C., s.v. 'Neith', in: Redford 2001.

Stengel, P. Opferbräuche der Griechen, Leipzig: Teubner, 1910.

Usener, H. 'Milch und Honig', Rheinisches Museum für Philologie, 51, 1902, 117-145.

Ventris, M. and Chadwick, J. (eds.) Documents in Mycenaean Greek, $2^{\text {nd }}$ ed. by J. Chadwick, Cambridge: Cambridge University Press, 1973.

Weilhartner, J. 'Oil and Honey on some of the Linear B-Offering Tablets from Knossos: considerations about their possible application', Journal of the Prehistory of Religions, 16-17, 2002-2003, 46-52. . Mykenische Opfergaben nach Aussage der Linear B-Texte, Vienna: Verlag der Österreichischen Akademie der Wissenschaften, 2005.

West, M.L. The East Face of Helicon: West Asiatic Elements in Greek Poetry and Myth, Oxford: Oxford University Press, 1997.

Zecchi, M. 'On the Offering of Honey in the Graeco-Roman Temples', Aegyptus 77, 1997, 71-83.

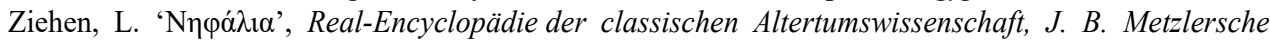
Verlagsbuchhandlung, 16, 1934, 2482-2489. 


\title{
АНГУС БОУВИ \\ Универзитет у Оксфорду \\ Квинс Колеџ \\ РИТУАЛНА УЛОГА МЕДА \\ У ДРЕВНОМ ЕГИПТУ, ХЕТИТСКОМ ЦАРСТВУ И ГРЧКОЈ
}

\begin{abstract}
Резиме
Овде је представљено упоређење употребе меда у ритуалним контекстима култура древног Египта, Хетитске државе и Грчке и показане су важне међусобне разлике. У Египту, или прецизније Доњем Египту, мед је играо важну улогу у краљевским ритуалима који су повезивали моћ, здравље и плодност богова и фараона. Супротно томе, код Хетита, иако укључен у важне обреде, нарочито оне којима је намеравано 'омекшавање' богова и привољавање да се појаве међу боговима и људима, мед је само један од много чинилаца. У Грчкој је изгледа постојала разлика између микенског периода, када мед (судећи у мери коју дозвољавају оскудни извори) није био ограничен на посебне типове богова, и архајској и класичној Грчкој, када је у значајној мери био везан за ритуале атипичне врсте, тј. обреде који су евоцирали древна времена или оне који су се тицали подземног света и мртвих. Чланак се завршава разматрањем ограничења која су својствена оваквим компарацијама и спекулацијама о разлозима за уочене разлике. Иако је грађа морала бити представљена са одабиром, наведен је широк распон оригиналних извора.
\end{abstract}

Кључне речи: мед, древни Египат, Хетити, Крит, античка Грчка, краљевски ауторитет, хтонски ритуали, дозивање (evocatio) богова, клетве, нормални и 'абнормални' ритуали.

(C) Faculty of Philosophy, Novi Sad, 2020

ISTRAŽIVANJA - JOURNAL OF HISTORICAL RESEARCHES 31, 7-23 